2019-03-20

\title{
How inclusion became exclusion: Policy, teachers and inclusive education
}

\author{
Done, Elizabeth
}

http://hdl.handle.net/10026.1/12781

10.1080/02680939.2018.1552763

Journal of Education Policy

Taylor \& Francis (Routledge)

All content in PEARL is protected by copyright law. Author manuscripts are made available in accordance with publisher policies. Please cite only the published version using the details provided on the item record or document. In the absence of an open licence (e.g. Creative Commons), permissions for further reuse of content should be sought from the publisher or author. 


\title{
How inclusion became exclusion: Policy, teachers and inclusive education
}

Elizabeth J. Done and Mandy J. Andrews

Plymouth Institute of Education, 502 Rolle Building, Plymouth University, Plymouth PL4 8AA, Devon, UK. Email: Elizabeth.done@plymouth.ac.uk; Tel. +441752585462; ORCID: 000-0001-6627-1928; Mandy.andrews@plymouth.ac.uk; 01752585462.

\begin{abstract}
It is almost two decades since a concept of inclusion as selective segregation was proposed as an alternative to the concept of full inclusion and inclusive education was reconfigured as providing children with varied educational settings in order to meet their needs. A version of this model of inclusive education subsequently gained political traction in England where the issue of segregated or mainstream provision is now constructed as a matter of parental choice and child voice. Meanwhile, the implications of this latest model of inclusive education for teachers and schools in a rapidly changing wider educational landscape have largely been ignored or reduced to a question of training. This paper explores how the inclusive education landscape has changed in England in recent years, charting recent key developments in areas such as policy, statutory guidance and teacher training, with particular reference to teacher workload and the positioning of teachers within political and polemical educational discourse.
\end{abstract}

Key words: Inclusive education; special educational needs; performativity; teacher workload.

Dr Elizabeth J. Done is a lecturer on the SENCo and Masters in Education Programmes at the Plymouth Institute of Education and a Visiting Fellow in Bristol University's Graduate School of Education. Liz previously taught at the A.U.W. in Khartoum and has published widely in the field of inclusion and poststructuralist theory.

Mandy Andrews manages the SENCO Programme at the Plymouth Institute of Education and is a lecturer in Early Childhood Studies.

Word count: 9335 (incl. title page / excl. running headers) 


\section{Introduction}

In a polemical paper published some years ago Powell and Tutt (2002) defended a concept of inclusive education that could be described, following Deleuze (2004, p. 167), as a 'dogmatic' image of inclusion, that is, one that was widely recognised as educational inclusion and functioned as a hegemonic and, therefore, incontestable common sense of what inclusion means. This model and subsequent developments in policy, statutory guidance and related areas are summarised below. We also explain how Deleuze's $(2004,164-213)$ theory around 'images of thought' provides a way of conceptualising socio-political assemblages in which 'everybody knows' (p. 165) that inclusive education involves the segregation of some children from their peers. Historically, segregation was achieved through the placement of such children in special schools whereas the current situation is somewhat more complex. Segregation now occurs in multiple ways in the context of a political social justice agenda that promotes integration as the dominant model of inclusive education whilst simultaneously sanctioning both educational segregation and exclusionary practices in mainstream settings.

Teachers feature prominently in inclusion-related policy discourse as the facilitators of inclusive education but are also charged with raising standards and improving the performance of their schools. We explore the implications of shifts in inclusion policy for teacher workload and argue that the major obstacle to meaningful inclusion is a neoliberal educational system in which the meeting of academic performance targets and supply of demonstrations of progress have become overriding political priorities. From a Deleuzian perspective, to consider different models of inclusion without envisaging a radical overhaul of such priorities is to miss the point (Deleuze 2004). Logically, the act or process of inclusion first requires some form of exclusion regardless of the model of inclusive education under consideration and teachers are unable to challenge exclusion when bound by normative concepts, accountability procedures and political discourses - what Ball and Olmedo (2013, 
p. 85), following Foucault (1982), would term neoliberal governmental technologies and Deleuze (1995, p. 177) would describe as data-driven de-individualising control.

The combining of a social justice or equity agenda (inclusive education) and a distinctly neoliberal political privileging of the capitalist market order (resulting in quasi-markets in education) is explained in Foucault's (2008) analysis of the ordoliberal school of neoliberal economic theory; state intervention is required to maintain that order and address any obstacles to the free and fair competition upon which it allegedly depends. We draw on Laurie and Shaw's (2018) conceptualisation of violent conditions or, more specifically, their concepts of structural and cultural violence derived from Galtung (1990) and their insistence on the materiality of common sense, in order to counter ordoliberal suggestions that free and competition is achievable through ameliorative social and educational policies. These authors mobilise concepts found in Deleuze (2004) and Deleuze and Guattari $(1994,2009)$ in order to analyse 'how injustice embeds itself in the flesh and bones of the world—a world that is never above or below the human subject but threaded into its very fibres' (Laurie and Shaw 2018, p. 2).

\section{Background}

The vehemence with which Powell and Tutt (2002) argue for the dogmatic image of inclusivity as selective segregation is, perhaps, indicative of the 'shock to thought' (Massumi 2002; Deleuze 2004, p. 185) that had been presented by proponents of an alternative model of inclusion as full inclusion or the ending of all segregated provision around this time (e.g. Slee and Allan 2001). Powell and Tutt's (2002, p. 43) response to the act of refusal which the demand for full inclusion implied was to invoke 'realism' in opposition to a perceived 'extremism' and, in Deleuze's terms (2004, p. 175), to reject an encounter or event that could change thinking around inclusion or 'awaken thought from its natural stupor'. The trope of common-sense realism or pragmatism continues to be evidenced in the literature relating to 
special educational needs and special education although, nowadays, starkly polarised positions tend to be avoided; in Norwich (2014), for example, full inclusion is reworked as a common long term vision but one that should not distract from current practicalities.

Common-sense realism within the special needs literature is typically framed as an ethical matter such that segregated specialist settings are deemed to be in some children's best interests, as argued in Powell and Tutt (2002). In later policy proposals, legislation and statutory guidance for schools, however, it functions to support a distinctively neoliberal political discourse of freedom of parental choice of educational setting; this purported freedom was formalised in the Children and Families Act (Department for Education [DfE] 2014a) and permits parents to decide whether a specialist or mainstream setting is the most appropriate for their child. In Foucault (1982), this freedom to choose is conceptualised as a biopolitical process of responsibilisation. It is a governmental practice through which the modern state instils a sense in every individualised subject that they are responsible for the consequence of their choices (Done and Murphy 2018), and Lilley (2014) has shown that the affective fall out of this 'freedom' to choose between mainstream and special schools can be anxiety and guilt rather than a sense of having been treated equitably.

Criticisms of the wider educational context in this special needs literature tend to be limited or confined to features that are mobilised in order to reinforce the dogmatic image of inclusion; it is assumed, for example, that special school placement protects children from the intensive scrutiny and heightened competitive individualism associated with mainstream testing practices. This assumption, however, neglects the increasingly intensive monitoring of progress which all types of educational setting are now required to undertake. Following Laurie and Shaw (2018), such intensive testing and monitoring can be construed as a form of cultural violence that works to reinforce disadvantage and limit the realisation of potential through the normalisation of social divisions. 


\section{How inclusion became exclusion}

We would also argue that the focus on current practicalities in Norwich (2014) clearly resonates with the common-sense economic realism that has pervaded the policy arena since the global economic crisis of 2008 , affecting both policy relating to inclusion and the schools which must implement that policy. Hence, the Green Paper entitled 'Support and Aspiration' (DfE 2011) which preceded the Children and Families Act (DfE 2014a) sought to address an alleged problem of over-identification of special educational needs that attracted additional funding for mainstream schools. Limited funding is now making the external support services which schools are advised to draw on in the Special Educational Needs and Disabilities (SEND) Code of Practice (Department of Health and Department for Education [DoH / DfE] 2015) difficult to access (DfE 2017a). Recent data shows that the downward trend in special need identification consistently evidenced in recent years and coinciding with a politics of austerity has been replaced this year by an increased identification (DfE 2018a), suggesting even greater pressure on schools.

It is noteworthy that schools rather than teachers are mentioned by Powell and Tutt (2002, p.45) in the context of accountability and performance monitoring and the capacity of mainstream schools to absorb children performing below National Curriculum (HMSO 1988) standards. Teacher workload generally is now acknowledged to be excessive (DfE 2018b, 2018c), as is the workload of teachers that combine their teaching role with that of coordinating special needs provision within their schools (Pearson, Mitchell and Rapti 2015). However, the training of teachers has been, and continues to be, the dominant theme within policy discourse relating to inclusion rather than workload, as if any governmental agenda and competing governmental agendas can be readily realised if only teachers are suitably and adequately trained (Done and Murphy 2018). Whereas Powell and Tutt (2002) emphasise the specialist skills available in specialist settings, the parental choice of setting enshrined in the Children and Families Act (DfE 2014a) has coincided with a growing body of literature 
aimed at initial teacher educators in which it is argued that these specialist skills are simply teaching skills that all teachers already do, or should, possess (Florian 2008). Recent guidance directed towards early years providers, where it is claimed that the stipulated early identification of special needs or diagnosable conditions is a matter of skill-acquisition, illustrates this point (DfE 2014b).

The dogmatic image of inclusive education (as inclusion through selective segregation and more recently through parentally-selected segregation), combined with an historical focus on the politics of inclusivity, has resulted in a relative neglect of the related issues of teacher workload and the availability of adequate resourcing. Indeed, it could be argued that the 'politics of blame' around standards in education evidenced since the 1990s (Thrupp 1998) has merely been expanded such that the capacity to deliver an inclusive educational system is largely perceived to be an issue of teacher readiness or, as in the Office for Standards in Education SEND Review (Ofsted 2010), a matter of improved teaching. Drawing on Sellar and Lingard's (2018) concept of 'catalyst data', that describes how affective responses to reported performance data can coalesce into a sense of crisis which policy makers then leverage, it can be argued that the Ofsted (2010) report served a similar catalytic function, prompting a political discourse and common-sense image of teachers in which they, or their lack of training, are understood to be the primary obstacle to inclusive practices in mainstream schools. The phrase 'quality first teaching', derived from the SEND Code of Practice (DoH / DfE 2015, section 1.24) and denoting differentiation and personalisation, is now widely invoked as if it were a novel empirical reality rather than a discursive construct or common-sense image that positions teachers as the solution to the problem of inclusion; as Deleuze and Parnet (2007, p. 23) argue, such images imply 'a whole organization which effectively trains thought to operate according to the norms of an established order or power, and moreover, installs in it an apparatus of power, sets it up as an apparatus of power itself'. 


\section{How inclusion became exclusion}

The discursive construction of teachers as the obstacle to inclusion could also be read as a form of cultural violence. As Laurie and Shaw $(2018,3)$ state, such violence can be abstract, anonymous and bureaucratic, and 'rendered banal and everyday through its repeated exposure and representation' (p. 4). It serves to distract attention from issues including, the erosion of professional autonomy, the inadequate funding available to schools, excessive teacher workloads and the affective import of neoliberal performativity for teachers and their pupils.

Much has changed since 2002 but much remains fundamentally unchanged. Before outlining our theoretical framework and subsequent developments, we offer a summary of the paper which has served as a useful starting point in our analysis. Powell and Tutt (2002, p. 44) argue strongly against full inclusion as the integration of all children, regardless of need, into mainstream schools; 'commonality of location' is rejected as the basis of inclusion and an inclusive education system is subsequently defined as one in which some children achieve equality of educational opportunity through placement in 'specialist settings' equipped to support their specific needs. This argument is supported by a Department for Education and Skills (DfES 2001, p. 21) report in which special schools (maintained and otherwise) were recognised as having 'a continuing and vital role to play within an inclusive education system'. Alluding to the Salamanca Statement and Framework for Action on Special Needs Education (UNESCO 1994) which promoted the concept of child-centredness, Powell and Tutt 2002, p. 46) maintain that increased availability of special school placements would ensure respect for the 'uniqueness' of all children. The Warnock Report (HMSO 1978) is criticised as singularly unhelpful in this regard as the umbrella term of 'special educational needs' (SEN) which it introduced encompassed physical disabilities but also cognitive and behavioural or emotional difficulties of varying degrees of severity and applied to approximately $20 \%$ of the school population (Powell and Tutt 2002, p. 44). 
As Powell and Tutt (2002) argue, this category of SEN included children with physical disabilities that might easily be integrated into mainstream classrooms but also children of limited cognitive ability that require considerable differentiation and those whose curriculum should be focused on 'therapeutic, sensory or developmental elements' (p. 45). In Powell and Tutt's (2002, p. 45) view, later contextual changes, specifically, the introduction of a National Curriculum (HMSO 1988) accompanied by an increasingly ascendant political discourse around educational standards served to reinforce the case for placing the latter two groups into specialist settings, as these changes created exclusionary pressures in their emphasis on academic performance and the ensuing mandated delivery of stipulated degrees of academic progress (p. 45). It is noted that this curriculum failed, in its very design, to include all children (Jordan and Powell 1994 cited in Powell and Tutt 2002, p. 44) and that subsequent national literacy and numeracy strategies (Department for Education and Employment 2000) exacerbated this exclusionary trend. It is against this backdrop that proponents of full inclusion are held to be promoting 'extreme views' that risk damaging the very children that they intend to help (p. 46).

\section{Theoretical orientation}

The concept of the dogmatic image derives from Deleuze's (2004) critique of established philosophical analyses of 'what it means to think' (p. 170) and the model of 'recognition' upon which they are based (p. 169). Deleuze (2004, p. 169) argues that, instead of challenging common-sense, Descartes produced an image of thought in which the cogito 'provides a philosophical concept for the presupposition of a common sense; it is the common sense become philosophical'. Recognition is defined as 'the harmonious exercise of all the faculties upon a supposed same object' (p. 169) and Deleuze illustrates this with Descartes' observations of a piece of wax: 'It is of course the same wax which I see, which I touch, which I picture in my imagination, in short the same wax which I thought it to be from 


\section{How inclusion became exclusion}

the start'. The model of recognition presupposes the cogito as a site for the 'collaboration of the senses for “everybody" - in other words, a common sense' (Deleuze 2004, p. 169). Kantian philosophy similarly privileges the "identity of the Self in the "I think" which grounds the harmony of all the faculties and their agreement on the form of a supposed Same object' (p. 169).

For Deleuze (2004, p. 175), the resulting image of thought is one in which thought is 'filled with no more than an image of itself, one in which it recognises itself the more it recognises things: this is a finger, this is a table. Good morning Theaetetus' (p. 175). It is the presumed universality of the cogito and of the objects of its recognition that permit statements such as '”Everybody recognises that ... "' (p. 63); but, in Deleuze's (2004) critique, it is precisely thought which relies on the model of recognition that is said to exist in a state of 'natural stupor' or not constitute thinking at all (p. 175). This state of stupor is to be distinguished from 'stupidity' which Deleuze (2004, p. 198) defines as a faculty for false problems, including problems which rely on common-sense and are 'evaluated according to the possibility of their finding a solution' (p. 199).

The problem of inclusion posed by Tutt and Powell (2002) is one of how children can be made to feel included in the absence of any fundamental change to the educational system and it would qualify as a false problem in Deleuze's (2004) terms because the proposed solution of simply re-defining inclusive education as continued segregation (accompanied by feelings of inclusion) is easily grasped within the prevailing socio-political context; but it is hardly a break with orthodoxy and it relies on common-sense recognition for traction. A further difficulty with appeals to common-sense is that, as Deleuze states, 'there is always an unrepresented singularity who does not recognise precisely because it is not everyone or the universal' (2004, p. 63). There may be no readily obvious practical solution to the alternative problem of how to create an educational system in which exclusion no longer occurs; 
however, the posing of this problem does serve to open up thought to unforeseen possibilities and alter the terms of debate. Similarly, there are likely to be teachers who recognise 'quality first teaching' (TES 2014) as the common-sense solution to the problem of inclusion; but there will almost certainly be others who reject the deficit model of teachers that it implies and who question whether such teaching differs from something that they have been doing all along. Challenging orthodoxy is problematic once it becomes integral to a hegemonic educational discourse and to government policy or statutory guidance, and the question remains as to how common-sense functions to support certain social conditions and existing or modified orthodoxies beyond the model of recognition proposed by Deleuze (2004).

Just as Foucault rejects any suggestion that disciplinary power (1977) or biopolitical power (1982) is imposed upon a pre-existent subject, in Deleuze and Guattari (2009) the Cartesian presupposition of a thinking subject that exists prior to its social environment is rejected. Subjectivity is instead conceived as lacking a fixed identity and produced through a series of syntheses; recognition here is not about the representation of objects in human consciousness as a cognitive process but, rather, 'it is all life and lived experience' (p. 19) or what Laurie and Shaw (2018, p. 5), drawing on Marx (1990), deem to be material conditions of existence. On this account, the subject is produced by these conditions rather than being their precondition; it is 'always-already immersed and worldly — in the midst of conditions. There is no pure starting point between condition, world, and subject, just endless syntheses' (p. 6).

Deleuze and Guattari (2009) maintain that the Cartesian 'I think' actually presupposes an 'I feel at an even deeper level' - a 'primary emotion' (p. 18) such that 'the lived state comes first in relation to the subject that lives it' (p. 20); rather than pre-existing its prevailing social conditions, the Deleuzo-Guattarian subject is continually produced by its social and material environment. Accordingly, as Laurie and Shaw (2018, p. 8) argue, it makes more sense to 


\section{How inclusion became exclusion}

refer to a sentio as opposed to a cogito, and these authors draw on this analysis of subjectivity to conceptualise social conditions as forming a 'geography of being' that dictates 'what is possible, what is real, and what is impossible and what is unreal'. The suggestion here is that common-sense is the 'collective sensation of being in and amongst conditions' (neoliberal capitalist conditions); and it is through the lived experience of such conditions that the human subject is produced along with taken for granted assumptions that may conceal, or normalise, forms of cultural violence (Laurie and Shaw 2018, p. 13). Historical and social conditions function as 'spaces of sensation in which reality is felt and made intelligible' (p.13); hence, common-sense can be read as both an affective realm and an ontological condition.

The structural violence which cultural violence sustains is described by Laurie and Shaw (2018, p. 3) as a 'diffuse' and institutional form of violence that 'stunts an individual's ability to develop and realize their full potential' and which, crucially and from an ethical perspective, fails to rectify this gap between the actual and the virtual. The virtual can be understood as the field of forces or potentials from which the actual emerges and that emergence is limited by prevailing social conditions (Deleuze 2004) and capitalist relations (Deleuze and Guattari 2009). Taking the sentio rather than the cogito as an analytical starting point is useful in explaining why disadvantaged children may feel that their aspirations are misplaced despite political and educational discourses claiming equality of opportunity and a neoliberal capitalist market order which values competitive individualism.

We would describe the categorisation of some children as SEN as one form of the normalised and taken for granted cultural violence posited by Laurie and Shaw (2018, p. 9) and their use of the concept of the 'truncated life' is particularly apt when the way in which categorisation, and neoliberal marketisation, can work to limit the life potential of many children is considered. This concept derives from Deleuze's (2004) analysis of problems and their solutions which, in turn, relies on a distinction between the possible and the virtual. 
Reality is truncated within the thresholds of possible experience where 'violent conditions police or constrict the passage between the virtual and the actual' and work to 'limit and truncate who and what is actualized in the world, and how' (Laurie and Shaw 2018, p. 8). Conditioning implies forces that constitute 'restrictive materialities' (p. 8) and we would argue that data released by the DfE (2018a) shows that forces related to class, gender and ethnicity are at play in the actualisation of the body of pupils labelled as SEN. Boys, for example, are twice as likely as girls to acquire an SEN label and are similarly overrepresented in SEN categories that are suggestive of Foucault's (1982) theorisation of biopolitical power as a means of managing and controlling potentially unruly subpopulations. Although Laurie and Shaw (2018, p. 15) do not acknowledge that their solution to such problems (including the limiting of the life chances of young people through labelling, discrimination and material disadvantage) derives from Foucault (1986), care of the self-and therefore others is recommended along with praxis and pedagogy. In Deleuze (2004), praxis (as action informed by theory) would dictate the disruption of common-sense assumptions, thinking into the unknown and proposing solutions that do not merely reproduce those assumptions. As Laurie and Shaw (2018, p. 15) state: 'Violence must always be nourished - with energy, matter, discourse, habit, affect, and the legitimacy bestowed by easy routine. That is, violent conditions demand common sense'.

The suggestion that common-sense is historically specific and functions as an ontological condition explains why it is that referring to children as 'SEN pupils' feels so right to so many, and why the concept of full inclusion once provoked such strong reactions as Tutt and Powell's (2002, p. 43) charge of 'extremism'; as Grosz (2011) states, novel concepts can disorientate and disrupt our geographies of being. That geography of being for teachers' now includes routinely excessive working hours (NASUWT 2018), additional responsibilities (DoH / DfE 2015) and, most recently, a political discourse that introduces the false problem 


\section{How inclusion became exclusion}

of personal time management in relation to workload capacity (DfE 2018a). The latter individualises the issue of workload, inviting the responses of "'So that's what it was" and "So it's me!"” (Deleuze and Guattari 2009, p. 20); such self-recognition is facilitated by conditions of political blame (Thrupp 1998) and a neoliberal common-sense economic realism where it is understood that we must all do more for less in the aftermath of the global financial crisis. So too with discourses around inclusive education; prevailing socio-political conditions mean that teachers will inevitably be responsibilised whichever model of inclusion is preferred (Foucault 1982).

To summarise, for Deleuze (2004), it is a shared philosophical and common-sense belief about what thought is - a dogmatic image of thought, that inhibits thinking as a creative encounter with the unthought or the new; hence, 'to create is first of all to engender thinking in thought' (2004, p. 185). Thinking is the production of concepts which can open up a 'thing, object, process or event - the real - to becoming other', thereby initiating a movement beyond ourselves, a 'possibility of being otherwise' rather than simply 'affirming what we are' (Grosz 2011, p. 81, p.78). It not only involves an encounter that 'moves the soul' and 'forces it to pose a problem' (Deleuze 2004, p. 176) but, in its disruption of familiar geographies of being, it also involves a certain violence: 'The violence of that which forces thought develops from the sentiendum [I feel] to the cognitandum [I think]' (p. 177).

\section{Subsequent developments}

\section{International context}

The suggestion that much and little has changed since 2002 is illustrated by events internationally. Armstrong $(2013$, p. 7) notes that inclusivity remains a contested concept across many national contexts and poses the question as to whether inclusive education has been 'reduced to a new name for "special education"”. The 'rhetoric of inclusion' has become a routine and incontestable feature of social and educational policy discourse such 
that 'inclusion may end up meaning everything and nothing at the same time' (Armstrong et al. 2011, p. 31). The latter authors identify four distinct factors in the mid-1980s and early 1990s that underpinned calls for educational inclusion: teacher and parent objections to restricted access to, and participation in, mainstream settings based on assumptions about levels of disability and a complex system of identifying and allocating resources to children with additional needs who risked removal from regular classrooms for much of their school life (Slee 1993); disability activism and the formulation of a social model of disability (Oliver 1996); concern about how difference is managed following the introduction of educational marketisation and attendant school performance pressures; and, lastly, the linking of educational inclusion with economic development within international bodies such as the United Nations (Armstrong et al. 2011, p. 30).

The eventual response to these calls at the level of international governance is deemed by Armstrong et al. (2011, p. 33) to be 'one of the most significant events of the twenty-first century'; this was the United Nations General Assembly's adoption of the Convention on the Rights of Persons with Disabilities in 2006 which came into force in May 2008. This rule acknowledges the social model of disability (Goodley 2014) in that disability is described as an 'evolving concept' resulting from 'the interaction between persons with impairments and attitudinal and environmental barriers that hinders their full and effective participation in society on an equal basis with others' (UN 2006, p. 1). The Convention states that 'States Parties shall ensure an inclusive education system at all levels' and requires them to provide 'individualised support in environments that maximize academic and social development, consistent with the goal of full inclusion' (UN 2006, p. 16, 17).

Whilst the UN's (2006) reference to full inclusion is highly significant, it must be noted that international policy statements which promote the principle of inclusivity also emphasise that educational inclusion is more economically efficient than a segregated system, that is, it 


\section{How inclusion became exclusion}

affords opportunities to reduce or control public expenditure (Done, Murphy and Knowler 2015). A similar theme was evidenced in the preceding Salamanca Statement (UNESCO 1994) (Lloyd 2008). So, although Armstrong et al. (2011) refer to tensions within the aforementioned UN Convention (2006), our view is that economic efficiency was, and remains, the political priority and that these policy documents reflect wider structural changes associated with neoliberal economics and globalisation. Hence, 'full inclusion' is explicitly referred to as a 'goal' or aspiration but no time frame for its realisation is specified. Instead, as merely a 'goal', implementation can be indefinitely deferred (Slee and Allan 2001), permitting a discourse of social justice whilst simultaneously allowing governments to privilege national economic priorities over the principle of inclusivity. As a deferrable 'goal', the United Nation's (2006) invocation of full inclusion functions as a form of 'cruel optimism' (Moore and Clarke 2016), inviting teachers who support this model of inclusive education to accept allegedly short term measures as the groundwork for the longer term realisation of their objectives even though those measures may contradict their own pedagogic values.

The UN's (2015) ‘2030 Agenda for Sustainable Development' entitled 'Transforming Our World' presents a vision for sustainable global economic and social development which is repeatedly summarised in a phrase adapted from the U.S. Congress Act of 2001 (No Child Left Behind), hence, 'no one will be left behind' (UN 2015). This document also reiterates UN recognition of national sovereignty and national priorities and, consequently, can be read as a similar exercise in institutionalised deferral. New and ambitious goals are outlined even as it is simultaneously acknowledged that progress towards the Millennium Development Goals set some fifteen years previously has been highly uneven (UN 2015, 3/35, art.16). One such goal is that of 'providing inclusive and equitable quality education', at all levels and including 'vocational training', regardless of 'disabilities' and other sources of vulnerability, 
thereby equipping young people to 'exploit opportunities' and leading to what is described as a 'demographic dividend' and 'cohesive communities' (3/35 art. 25). Member states are to monitor progress towards these SDGs, providing the UN with relevant data, in what Laurie and Shaw (2018) might characterise as a chronopolitical feature of neoliberal political discourse. Deferral entails the discursive painting of an image of the future and concomitant suggestion that there will be inexorable progress towards its realisation despite current conditions. Dogmatic images work to support the sense making of subjects, including their negotiation of evident tensions between the injustices of the neoliberal present and this promised future. It could be argued that the repeated mentions of inclusion across the SDG report (UN 2015) are designed to produce a dogmatic image of inclusivity, that is, a common sense understanding of movement in that direction despite persistent and numerous exclusionary mechanisms.

\section{Domestic context}

Despite the UN (2006) rule, successive governments in England have endorsed segregation through special education and simply redefined inclusive education accordingly (DfES 2001, p. 21; DoH / DfE 2015). The Children and Families Act (DfE 2014) formalises this indefinite deferral of full inclusion in a typically neoliberal discourse of parental freedom to choose the most appropriate type of educational setting for their child. This legislation grants right of access and participation for children with disabilities or those designated as having special needs but qualifies this right by stating that schools are not required to ensure participation in activities where the cost is deemed to be prohibitively high or economically inefficient (Done, Murphy and Knowler 2015). The marketisation and academisation of the English education system in recent years has ostensibly expanded the choices available to parents; however, Exley (2014) has demonstrated that a rather more nuanced understanding of public support for choice is required. In relation to social deprivation, Exley (2014) notes 


\section{How inclusion became exclusion}

the growing evidence that parental choice in a quasi-market actually works to exacerbate segregation. The authors support a postgraduate programme designed for teachers in varied educational settings in England who are also SENCos (special educational needs coordinators) (Done, Murphy and Knowler 2015) and each teacher enrolled on this programme describes their setting and the key issues which confront them as SENCo; anecdotally, we regularly encounter teachers from mainstream schools in areas of high social deprivation where over forty percent of pupils are SEND-designated compared to a national average of $14.4 \%$ (DfE 2017b).

Statutory guidance linked to the 2014 Children and Families Act - the SEND Code of Practice (DoH / DfE 2015), incorporates both the broad and narrow definitions of inclusion proposed by Ainscow et al. (2006); the former requires schools to create and maintain an inclusive ethos while the latter concerns specific groups of student. The 'fragmented' definition of Armstrong et al. (2011, p. 31), whereby categories are broken down into subcategories, is also evidenced and existing categories are modified with SEBD (social, emotional, behavioural difficulties) becoming SEMH (social, emotional, mental health). A further major change is that teachers are now responsible for all SEND-designated pupils in their class whereas previously a SENCo would assume this responsibility. Teachers must follow a staged process known as the graduated approach comprising waves of targeted support before applying for an Education, Health and Care Plan that attracts additional funding for a specific child with a diagnosable condition. The role of SENCos is now more strategic and includes the organisation of training for staff. Training initiatives frequently centre on particular diagnosable conditions in the context of departmental demands that teachers contribute to the early identification and diagnosis of such conditions as, for example, in Code-related guidance directed at early years education providers (DfE 2014b). 
Lehane (2017) has undertaken a content analysis of the latest SEND Code of Practice (DoH / DfE 2015) and identifies a limited concept of inclusivity which can be summarised as maximisation of the proportion of children that can be prepared for eventual incorporation into the labour force or enhancement of the prospect of future economic productivity. The exclusionary implications are self-evident. Indeed, the current educational landscape in England is suggestive of an inverse relationship between inclusive political rhetoric and exclusionary mechanisms; at the same time that schools are working to ensure an inclusive ethos (as acceptance of difference and diversity), temporary and permanent exclusions are increasing (Gass-Poore and Woolcock 2018) and PRUs (pupil referral units) - both within and beyond school sites, are expanding (Weale 2017). It would appear that the dogmatic image of inclusive education has been reinforced by changes such as marketisation and academisation; hence, it has been suggested that academies, although bound by the SEND Code of Practice (DoH / DfE 2015) (Roberts 2017, p. 10), are declining to enrol SENDdesignated children (Norwich and Black 2015). The number of special free schools is increasing and will continue to increase following the introduction of a new tender mechanism entitled the Local Authority Commissioned Special Schools process (New Schools Network 2018). Anecdotally, teachers from small mainstream independent schools where the proportion of the school population designated as SEN is approaching fifty percent report that parental expectations are that a higher level of support will be provided than is possible in non-fee paying mainstream settings; meanwhile, teachers in mainstream statemaintained schools report pressure from parents for diagnoses in the belief that a dedicated teaching assistant will then be provided. Teachers from grammar schools report that pupils awaiting diagnoses for conditions such as autism cannot access external support services since, as high academic performers, they are deemed low priority; and that SEND-designated pupils are excluded from foreign language courses given a perceived risk of low attainment 


\section{How inclusion became exclusion}

and the potentially negative impact on school data. As noted above, marketisation has resulted in the concentration of SEND-designated children in maintained mainstream schools in areas of high social deprivation.

A political discourse around standards and associated practices of school performance monitoring and school inspection have undoubtedly impacted teachers in varied ways, but the effect on SEND-designated pupils is less clear. It is certainly the case, as Tutt and Powell (2002) predicted, that SEND-designated pupils in mainstream settings are subject to intensive levels of monitoring; schoolwide software which monitors academic attainment and progress in core subjects is designed to identify pupils who are falling behind age related expectations and facilitate ameliorative intervention. The type of software used also permits data analysis by category of disability or special need by senior management teams and SENCos, and the former identify the collection of SEN-related data as a contributory factor in excessive workloads (DfE 2018b, 2018c, p. 29). In order to secure external support or additional funding for a specific child, schools must compile a detailed evidence trail of support provided through graduated waves of intervention (DoH / DfE 2015). Selected disabilities and needs require a range of alternative tests in order to generate data that permits the monitoring of progress in non-academic areas such as emotional development. The SEND Code of Practice creates additional pressures for teachers as it requires schools to 'regularly and carefully review the quality of teaching' through teacher observations where the objective is to ascertain whether it is poor teaching that is the cause of pupil underachievement relative to stipulated expectations (DoH / DfE 2015, p. 99).

Whereas Deleuze's (1995) concept of the control society emphasises the 'dividualising' effects of the large data sets that are associated with school performance monitoring and league tables, the current model of inclusive education ensures that both teachers and their pupils with, or likely to be identified as having, special needs are subject to a twofold process 
comprising both routine dividualising surveillance (through their regular contribution to national data sets) and a highly individualised scrutiny. In Foucault (1982), both are conceived as 'modes of objectification that transform human beings into subjects' (p. 777) and as technologies of government associated with the modern state. Foucault (1982, p. 784) describes the novel forms of knowledge necessitated by a historical shift from pastoral to biopolitical power: one 'globalizing and quantitative, concerning populations' and the other 'analytical, concerning the individual'. Education is identified as one of several individualising knowledge practices that are integral to the biopolitical power of the modern state, i.e. to the power technologies through which the state seeks to regulate the populations within its jurisdiction (p. 787). The collection of SEND-related data can be conceptualised, following Foucault (1982), as one of many 'systems of differentiation' (p. 792) and 'dividing practices' (p. 777) within education; SEND-designated pupils are scrutinised collectively as a proportion of a school's population and as contributors to the proportion of specific diagnosable conditions within that school's SEND population, and such data is aggregated at a national level.

Despite the disengagement of teachers from computerised pupil progress monitoring noted by Schildkamp and Kuiper (2010), given its use in monitoring teacher performance, and the manipulation of data in that event (Ball 2003), SEND-related statutory guidance has ensured that some teachers will spend more time than ever collecting data and compiling evidence trails and that senior management teams have ever more data to analyse. There is to date, however, no national evaluation of the impact of this statutory guidance on pupils. Thompson and Cook (2014, p. 253, 2017) have noted the extent to which the pastoral care element of teaching has been side-lined by discourses related to academic achievement and performance management, and for SEND-designated pupils such care is likely to take the form of a targeted intervention that involves the collection of pre and post intervention data to quantify 


\section{How inclusion became exclusion}

its effectiveness. Governmental attention is now being directed towards the early years work force (DfE 2014b; NASEN 2018) where the concept of care risks being reduced to the systematic and evidence-based early identification of special needs which warrant monitoring and intervention.

The shift of responsibility towards teachers outlined in the latest SEND Code of Practice (DoH / DfE 2015) was designed to facilitate inclusion as integration and challenges previous notions of distributed expertise within schools whereby teachers were expected to rely on support from the school's SENCo. Teachers themselves are now expected to develop expertise in the diagnosed conditions of children within their classrooms and SENCos are charged with addressing gaps in staff knowledge and understanding, and checking that appropriate teaching practices are being adopted. We are not aware of any research into how collegial relations have been affected by this shift but we would argue that there are implications for the relational agency envisaged by Edwards (2007); such agency involves collective sense-making and reciprocity in decision-making around a particular child whereas SENCos are now effectively charged with policing their colleagues to ensure compliance with SEND-related statutory guidance. A concern raised by Edwards $(2007$, p. 10) is the diminished time available for the development of professional judgement when trainee teachers are obliged to follow pre-determined lesson plans in classrooms in the absence of more experienced teachers; it is argued that concerns which invite deviation from such plans tend to be ignored rather than functioning as sites for professional learning. It is precisely this type of learning which would be drawn on in collective sense-making around SEND-related matters, implying a wider context in which newly trained teachers have more responsibility but fewer opportunities for learning to rely on their own professional judgement whilst being policed by the very SENCos whose support they may require more than ever. This situation is complicated where, as is sometimes the case, the SENCo role has been allocated to a member 
of the school staff who has minimal teaching experience and is not part of the senior management team yet required by the Code (DoH / DfE 2015) to assume a strategic leadership role.

Slee (2013, p. 903) has suggested that the marked proliferation of diagnostic categories over recent decades, as evidenced in the DSM (Diagnostic and Statistical Manual of Mental Disorders) (APA 2013), has led to teachers lacking confidence around teaching the very type of pupil that, historically, would have not been diagnosed and categorised as having special needs. It can be argued that the issue of confidence typically functions as a rationale for greater control and management of specific educational sub-sectors in governmental discourse; for example, it is suggested that the call for early years teachers to contribute to early SEN identification will be fulfilled once training has produced the requisite level of confidence (DfE 2014b). In reality, the acquisition of confidence hinges on many factors, including the availability of adequate funding to deliver appropriate support to all pupils. Highlighting this aspect of teaching serves to obscure varied objections to governmental agendas; hence, anecdotally, we have encountered teachers who resist focusing on particular diagnosable conditions given their concern about the mental health of the whole school population within a competitively individualistic and inequitable educational culture, and others who strongly object to the categorisation of young children in early years settings. Governmental discourse individualises confidence as a condition of ameliorative intervention through SEND-related training just as SEND-designated children are subject to normative interventions.

\section{Concluding remarks}

It has been argued that neoliberal educational culture tends to exacerbate exclusionary pressures and mechanisms despite hegemonic political discourses which construct education as already inclusive or approaching inclusivity and teachers' professionalism as the capacity 


\section{How inclusion became exclusion}

to deliver a social justice agenda through compliance with the relevant statutory guidance and participation in training that is designed to enhance their skill base and awareness of varied diagnosable conditions. Schools are simultaneously charged with optimising academic attainment and evidencing their performance in order to compete within quasi-markets, prompting the monitoring of individual teacher performance. We have suggested that both teachers and pupils are now subject to intensive scrutiny which both dividualises (Deleuze 1995) and individualises (Foucault 1982), and that legislation and statutory guidance relating to inclusion and additional needs has further intensified such scrutiny, compounding workload pressures for educational practitioners and producing a heightened risk of exclusion or segregation for many pupils. Following Laurie and Shaw (2018), such conditions have been conceived as a form of cultural violence which is sustained by common-sense assumptions associated with discourses around equality of educational opportunity and inclusion, and a dogmatic image of inclusivity (as selective or selected segregation) that is clearly loaded with ambiguities and contradictions.

The ostensible rationale for segregated special education has certainly changed due to an ascendant neoliberal political discourse of parental choice (DfE 2011, 2014a) and a SEND Code of Practice (DoH / DfE 2015) that requires all teachers to take responsibility for all children, including those whose needs may be multiple and complex. Powell and Tutt's (2002) argument that special schools are a site of expertise that is not found in mainstream schools is arguably less applicable today. However, their suggestion that children should not be exposed to educational environments in which repeated assessment is the norm and academic attainment is prioritised through governmental agendas remains valid. We would argue that this suggestion is applicable to all children. Also, like Slee (2013), we maintain that the primary object of criticism when considering models of inclusive education should be neoliberal educational systems and cultures since the competitive individualism that they 
promote, and attendant concerns about pupil mental health, work to reinforce the case for segregated provision.

As Slee (2013, p. 905) and others (Done et al. 2015) have noted, at both the level of global governance and domestic policy, declarations of commitment to inclusive education as full inclusion are invariably accompanied by escape clauses based on economic priorities which function to legitimise exclusionary practices. Funding issues are exacerbating such practices (Richardson 2018). Meanwhile, the teaching profession is discursively positioned as the facilitator of, or obstacle to, inclusivity and carefully managed through successive policy developments, onerous data generation and management practices, and numerous training initiatives. In this context, the individualisation of teacher performance and categorisation of schools through inspection regimes resonates with the individualisation of medical and psychological 'pathologies' and the categorisation of groups of pupils according to a deficit model. Dogmatic images of thought as an individualised cogito, and of inclusivity as selective or selected segregation, work to support a common sense understanding that some teachers must be held to account and some pupils must be labelled and segregated (Deleuze 2004; Deleuze and Guattari 1994). Far from representing a form of 'extremism' (Powell and Tutt 2002, p. 43), critical disability theory reminds us that acts of refusal can disrupt common sense understandings and underline the urgency of feeling and thinking differently.

To conclude, Deleuze, Deleuze and Guattari, and Foucault can be situated within a philosophical trajectory of immanence that contains Spinoza and Nietzsche and focuses on the conditions of 'real experience' as opposed to a trajectory of transcendence which relies on concepts such as God, Self or World (Smith 2003, p. 46, p. 58). The former trajectory lends itself to the analysis of power relations (Rölli 2004) and to an ethics which, contra Tutt and Powell (2002), is not reliant on a presumed common sense but, instead, is about thinking differently in order to challenge hegemonic discourse and representations. Following Smith 
(2003, p. 63), the difference between these trajectories must be evaluated in the ethicopolitical domain.

The fundamental question of ethics is not 'What must I do?' (the question of morality) but rather 'What can I do?' Given my degree of power, what are my capabilities and capacities? How can I come into active possession of my power? How can I go to the limit of what I 'can do'? The political question follows from this, since those in power have an obvious interest in separating us from our capacity to act. (Smith 2003, p. 62).

The process of responsibilisation--of pupils (for their own life trajectories), parents (for their children's life trajectories) and teachers (for all children's life trajectories), suggests how biopolitical power functions to diminish the neoliberal subject's capacity to act (Foucault 1982) whilst Deleuze (2004) underlines the 'power-drenched determination of forms of thinking and acting' (Rölli 2004, p. 70). The immanent perspective of both explains how empirical reality comes to be viewed as natural and legitimate (a common sense) and exposes the power relations and social conditions which produce that sense of naturalness and legitimacy (p. 69). As Rölli (2004, p. 69) states, Deleuze's ontology of immanence 'reveals itself as excluding de jure concentrations of power [ ] thereby making them comprehensible as facts with regard to their causal conditions'. Thinking differently about inclusion and inclusive education first of all entails analysis of current practices and their conditions, but it also implies an immanent process of production, unforeseen becomings, empowerment and creation of the new.

\section{References}

Ainscow, M., T. Booth, A. Dyson, P. Farrell, J. Frankham, F. Gallannaugh, A. Howes, and R. Smith. 2006. Improving Schools, Developing Inclusion. London: Routledge. 
APA (American Psychiatric Association) 2013. Diagnostic and Statistical Manual of Mental Disorders $V$. Washington, DC: APA Publishing.

Armstrong, A. C. 2013. Collaboration, Partnerships and Alliances: Perspectives on Erasmus Mundus MA/Magistr in Special Educational Needs. International Journal of Inclusive Education 17 (4): 364-376.

Armstrong, D., Armstrong, A.C. and Spandagou, I. 2011. Inclusion: By Choice or by Chance? International Journal of Inclusive Education 15 (1): 29-39.

Ball, S.J. 2003. The Teacher's Soul and the Terrors of Performativity Journal of Education Policy 18 (2): 215-228.

Ball, S.J. and Olmedo, A. 2013. Care of the Self, Resistance and Subjectivity under Neoliberal Governmentalities. Critical Studies in Education 54 (1): 85-96. doi: $10.1080 / 17508487.2013 .740678$

Deleuze, G. 1995. Negotiations: 1975-1990. New York, NY: Columbia University Press.

Deleuze, G. 2004. Difference and Repetition. London: Continuum.

Deleuze, G. and Guattari, F. 1994. What is Philosophy? New York, NY: Columbia University Press. 
Deleuze, G. and Guattari, F. 2009. Anti-Oedipus. London: Continuum.

Deleuze, G. and Parnet, C. 2007. Dialogues 11. New York: Columbia University Press.

Department for Education 2011. Support and Aspiration: A New Approach to Special Educational Needs and Disabilities: A Consultation (The Green Paper). London: DfE.

Department for Education 2014a. Children and Families Act (2014). London: DfE.

Department for Education 2014b. Early Years: Guide to the 0 to 25 SEND Code of Practice. London: DfE.

Department for Education 2017a. Supporting Mental Health in Schools and Colleges: Quantitative survey. http://dera.ioe.ac.uk/29743/1/Supporting_Mental-

Health_survey report.pdf

Department for Education (DfE) 2017b. Special Educational Needs in England: January 2017.

https://www.gov.uk/government/uploads/system/uploads/attachment_data/file/633031/SFR37 2017 Main_Text.pdf

Department for Education 2018a. Special Educational Needs in England-January 2018. https://assets.publishing.service.gov.uk/government/uploads/system/uploads/attachment_data /file/729208/SEN_2018_Text.pdf 
Department for Education 2018b. Policy Paper: Reducing Teacher Workload.

https://www.gov.uk/government/publications/reducing-teachers-workload/reducing-teachersworkload

Department for Education 2018c. Exploring Teacher Workload: Qualitative Research. DfERR768.

https://assets.publishing.service.gov.uk/government/uploads/system/uploads/attachment_data /file/686734/Exploring teacher_workload.pdf

Department for Education and Skills 2000. National Literacy and Numeracy Strategies:

Guidance on Teaching Able Children. London: DfEE.

Department for Education and Skills 2001. Inclusive Schooling. London: DfES.

Done, E.J. and Murphy, M. 2018. The Responsibilisation of Teachers: A Neoliberal Solution to the Problem of Inclusion. Discourse: Studies in the Cultural Politics of Education 39 (1): 142-155.

Done, E.J., Murphy, M. and Knowler, H. 2015. Mandatory Accreditation for Special Needs Coordinators: Biopolitics, Neoliberalism and the Deleuzo-Guattarian 'War Machine'. Journal of Education Policy 30 (1): 86-100.

Edwards, A. 2007. Relational Agency in Professional Practice: A CHAT Analysis. Actio: An International Journal of Human Activity Theory 1: 1-17. 
Exley, S. 2014. Are Quasi-Markets in Education What the British Public Wants? Social Policy and Administration 48 (1): 23-44.

Florian, L. 2008. Special or Inclusive Education: Future Trends. British Journal of Special Education 35 (4): 202-208.

Foucault, M. 1977. Discipline and Punish: The Birth of the Prison. New York: Vintage.

Foucault, M. 1982. The Subject and Power. In Michel Foucault: Beyond Structuralism and Hermeneutics, edited by H. Dreyfus and P. Rabinow, 208-226. Chicago, IL: University of Chicago Press.

Foucault, M. 2008. The Birth of Biopolitics: Lectures at the Collège de France 1978-1979, edited by Michel Senellart, translated by Graham Burchell. New York: Palgrave.

Galtung, J. 1990. Cultural Violence. Journal of Peace Research 27, 291-305.

Gass-Poore, J. and Woolcock, N. 2018. School Exclusion Rates Linked to Violent Youth Crime. The Times, 2 May. https://www.thetimes.co.uk/article/school-exclusion-rates-linkedto-violent-youth-crime-xm97hfmxj

Goodley, D. 2014. Dis/Ability Studies: Theorising Disablism and Ableism. London: Routledge.

Grosz, E. 2011. Becoming Undone. Durham, NC: Duke University Press. 
HMSO (Her Majesty's Stationery Office) 1978. Special Educational Needs: Report of the Committee of Enquiry into the Education of Handicapped Children and Young People. London: HMSO.

HMSO 1988. Education Reform Act 1988. London: HMSO.

Jordan, R. and Powell, S. 1994. Whose Curriculum? Critical Notes on Integration and Entitlement. European Journal of Special Needs Education 9 (1): 27-39.

Laurie, E.W. and Shaw, I.G.W. 2018. Violent Conditions: The Injustices of Being. Political Geography 65: 8-16.

Lehane, T. 2017. 'SEN's Completely Different Now': Critical Discourse Analysis of Three 'Codes of Practice for Special Educational Needs' (1994, 2001, 2015), Educational Review 69 (1): 51-67, DOI: 10.1080/00131911.2016.1237478

Lilley, R. 2014. Professional guidance: maternal negotiation of primary school placement for children diagnosed with autism, Discourse: Studies in the Cultural Politics of Education, 35(4), 513-526. DOI: 10.1080/01596306.2013.871226

Lloyd, C. 2008. Removing Barriers to Achievement: A Strategy for Inclusion or Exclusion? International Journal of Inclusive Education 12 (2): 221-236, DOI:

$10.1080 / 13603110600871413$ 
Massumi, B., ed. 2002. A Shock to Thought: Expression after Deleuze and Guattari. London: Routledge.

Marx, K. 1990. Capital: A Critique of Political Economy. London: Penguin Books.

Moore, A. and Clarke, M. 2016. Cruel Optimism: Teacher Attachment to Professionalism in an Era of Performativity, Journal of Education Policy 31 (5): 666-677, DOI:

$10.1080 / 02680939.2016 .1160293$

NASEN (National Association of Special Educational Needs) 2018. The Role of the Early Years SENCO (Special Educational Needs Coordinator). London:

NASEN. https://www.foundationyears.org.uk/wp-content/uploads/2018/05/The-role-of-theEarly-Years-SENCO.pdf

NASUWT (National Association of Schoolmasters Union of Women Teachers) 2018. Neglect of Teachers' Mental Health and Physical Health a National Scandal, Says NASUWT. 21 March 2018 https://www.nasuwt.org.uk/article-listing/teachers-mental-health-andphysical-health.html

New Schools Network 2018.NSN Welcomes New Special Free Schools Approvals. 29 March 2018. https://www.newschoolsnetwork.org/what-are-free-schools/free-school-news/nsn$\underline{\text { welcomes-new-special-free-school-approvals }}$

Norwich, B. 2014. Recognising Value Tensions That Underlie Problems in Inclusive Education. Cambridge Journal of Education 44 (4): 495-510. 
Norwich, B. and Black, A. 2015. The Placement of Secondary School Students with Statements of Special Educational Needs in the More Diversified System of English Secondary Schooling', British Journal of Special Education 42 (2): 128-151.

Ofsted 2010. The Special Educational Needs and Disability Review: A Statement Is Not Enough. Manchester: Ofsted.

Oliver, M. 1996. Understanding Disability: From Theory to Practice. London: Macmillan Press.

Pearson, S., Mitchell, R. and Rapti, M. 2015. I Will Be 'Fighting' Even More For Pupils Eith SEN: SENCO's Role Predictions in the Changing English Policy Context. Journal of Research in Special Educational Needs 15 (1): 48-56.

Powell, S. and Tutt, R. 2002. When Inclusion Becomes Exclusion, Education 3-13, 30 (2): 43-46, DOI: $10.1080 / 03004270285200221$

Richardson, H. 2018. Special Needs Cash Shortfall 'Leaves Thousands of Children Unplaced'. BBC News, 2 April. http://www.bbc.co.uk/news/education-43604865

Roberts, N. 2017. FAQs: Academies and Free Schools. Briefing paper, no. 07059, 17 November 2017. London: House of Commons Library. 
How inclusion became exclusion

Rölli, M. 2007. Immanence and Transcendence. Bulletin de la Societe Americaine de Philosophie de Langue Francais 14 (2): 50-74.

Schildkamp, K. and Kuiper, W. 2010. Data-informed Curriculum Reform: Which Data, What Purposes, and Promoting and Hindering Factors. Teacher and Education 26 (3): 482-496.

Sellar, S. and Lingard, B. 2018. International Large Scale Assessments, Affective Worlds and Policy Impacts in Education. International Journal of Qualitative Studies in Education doi: $10.1080 / 09518398.2018 .1449982$

Slee, R. 1993. The Politics of Integration: New Sites for Old Practices? Disability, Handicap and Society 8 (4): 351-60.

Slee, R. 2013. How Do We Make Inclusive Education Happen When Exclusion Is A Political Predisposition? International Journal of Inclusive Education 17 (8): 895-907.

Slee, R. and Allan, J. 2001. Excluding the Included: A Reconsideration of Inclusive Education. International Studies in Sociology of Education 11 (2): 173-192.

Smith, D.W. 2003. Deleuze and Derrida, Immanence and Transcendence: Two Directions in Recent French Thought. In Between Deleuze and Derrida, edited by John Protevi and Paul Patton, 46-66. New York: Routledge. 
TES (Times Educational Supplement) 2014. Narrowing the Gap Through Quality First

Teaching. TES, 29 July. https://www.tes.com/teaching-resource/narrowing-the-gap-throughquality-first-teaching-6153613

Thompson, G. and Cook, I. 2014. Manipulating the Data: Teaching and NAPLAN in the Control Society. Discourse: Studies in the Cultural Politics of Education 35 (1): 129-142.

Thompson, G. and Cook, I. 2017. The Logic of Data-sense: Thinking Through Learning Personalisation, Discourse: Studies in the Cultural Politics of Education 38 (5): 740-754.

Thrupp, M. 1998. Exploring the Politics of Blame: School Inspection and its Contestation in New Zealand and England. Comparative Education 34 (2): 195-209.

United Nations 2015. Resolution Adopted by the General Assembly on 25 September 2015, 70/1. Transforming Our World: The 2030 Agenda for Sustainable Development. New York, NJ: UN.

UNESCO 1994. The Salamanca Statement and Framework for Action on Special Needs Education. Paris: UNESCO.

Weale, S. 2017. School Exclusions Data in England Only 'The Tip of the Iceberg'. The Guardian, 10 October. https://www.theguardian.com/education/2017/oct/10/schoolexclusion-figures-date-england-only-tip-iceberg 